\title{
Dietary interventions as regulators of stem cell behavior in homeostasis and disease
}

\author{
Jesse S.S. Novak, Sanjeethan C. Baksh, and Elaine Fuchs \\ Howard Hughes Medical Institute, Robin Chemers Neustein Laboratory of Mammalian Cell Biology and Development, \\ The Rockefeller University, New York, New York 10065, USA
}

\begin{abstract}
Stem cells maintain tissues by balancing self-renewal with differentiation. A stem cell's local microenvironment, or niche, informs stem cell behavior and receives inputs at multiple levels. Increasingly, it is becoming clear that the overall metabolic status of an organism or metabolites themselves can function as integral members of the niche to alter stem cell fate. Macroscopic dietary interventions such as caloric restriction, the ketogenic diet, and a high-fat diet systemically alter an organism's metabolic state in different ways. Intriguingly, however, they all converge on a propensity to enhance self-renewal. Here, we highlight our current knowledge on how dietary changes feed into stem cell behavior across a wide variety of tissues and illuminate possible explanations for why diverse interventions can result in similar stem cell phenotypes. In so doing, we hope to inspire new avenues of inquiry into the importance of metabolism in stem cell homeostasis and disease.
\end{abstract}

Adult stem cells serve as the stewards of the body by maintaining homeostasis and repairing tissues in response to stress. For stem cells to carry out these tasks, they must balance self-renewal and commitment to differentiate. When exposed to insults such as inflammatory stimuli, pathogens, mechanical stress, or oncogenic stress, stem cells are faced with new hurdles to restore homeostasis. If they cannot cope, an imbalance can occur in the stem cell's equilibrium, which if left unchecked can place the tissue at risk for hyperproliferation, chronic wounding, and/or cancer.

During normal homeostasis, stem cells integrate cues from their local microenvironment or niche to maintain tissue equilibrium. These cues include signaling pathways (BMPs, WNTs, TGFßs, NOTCH, SHH, and growth factor/tyrosine kinase receptors), extracellular matrix (ECM) ligands (fibronectin, laminins, and collagens), mechanical forces, cell-cell interactions, and metabolites, all of which have been shown to impact stem cell behavior

[Keywords: caloric restriction; cell fate; cellular metabolism; fasting; high-fat diet; ketogenic diet; organismal metabolism; self-renewal; stem cells]

Corresponding author: fuchslb@rockefeller.edu

Article is online at http://www.genesdev.org/cgi/doi/10.1101/gad.346973. 120.
(Gonzales and Fuchs 2017; Intlekofer and Finley 2019; Fuchs and Blau 2020). In recent years, intracellular metabolites and metabolic pathways have gained particular attention as it was learned that they not only support growth and proliferation, but they can also work in conjunction with signal transduction pathways (Mihaylova et al. 2014; Martínez-Reyes and Chandel 2020; Jewell et al. 2013) and chromatin modifying enzymes to regulate gene expression (Ward and Thompson 2012; Schvartzman et al. 2018). Accordingly, metabolic inputs at all levels, from macroscopic dietary interventions to intracellular pathways, have been implicated in the fate decisions that are made by tissue stem cells.

Understanding how metabolism regulates stem cell function in vivo has begun to shed light on the convergence of phenotypes along the spectrum of normal homeostasis and cancer and possible therapeutic avenues for interventions that target metabolic pathways. To date, several methods have been employed to alter organismal metabolism using dietary interventions. The most thoroughly studied interventions include caloric restriction, prolonged fasting, ketogenic diet, and the high-fat "Western" diet (Table 1).

Engaging in caloric restriction, prolonged fasting, or a ketogenic diet elicits similar systemic changes to metabolic homeostasis, albeit through slightly different mechanisms. Caloric restriction, defined as either reducing calorie intake by $>20 \%$ over ad libitum feeding or merely lengthening the time between meals (Pugh et al. 1999), induces a state of ketogenesis that is recapitulated by a ketogenic diet. Prolonged fasting elicits a similar outcome, but here, the lengths of fasted versus fed periods is able to better control and distinguish it from a ketogenic diet.

During the fasted or nutrient-poor state, glucose levels decline and ketone biogenesis increases. The liver produces and releases into circulation the ketones acetone and $\beta$ hydroxybutyrate $(\beta-\mathrm{OHB})$. Ketone bodies then feed into the tricarboxylic acid (TCA) cycle as acetyl-CoA, thereby bypassing glucose oxidation, typically a major source of

(C) 2021 Novak et al. This article is distributed exclusively by Cold Spring Harbor Laboratory Press for the first six months after the full-issue publication date (see http://genesdev.cshlp.org/site/misc/terms.xhtml). After six months, it is available under a Creative Commons License (Attribution-NonCommercial 4.0 International), as described at http://creativecommons.org/licenses/by-nc/4.0/. 
Table 1. Comparison of properties and effects of dietary interventions

\begin{tabular}{|c|c|c|c|c|c|c|}
\hline & $\begin{array}{c}\text { Control chow } \\
\text { diet }\end{array}$ & $\begin{array}{l}\text { Pure caloric } \\
\text { restriction }\end{array}$ & $\begin{array}{l}\text { Prolonged } \\
\text { fasting }\end{array}$ & $\begin{array}{l}\text { Ketogenic } \\
\text { diet }\end{array}$ & $\begin{array}{l}\text { High-fat } \\
\text { diet }\end{array}$ & $\begin{array}{l}\text { Western } \\
\text { diet }\end{array}$ \\
\hline $\begin{array}{l}\text { Caloric } \\
\text { content }\end{array}$ & $\begin{array}{l}4 \mathrm{kcal} / \mathrm{gram} \\
\text { chow }\end{array}$ & $\begin{array}{c}\geq 20 \% \\
\text { decrease }\end{array}$ & $\begin{array}{l}\text { Unchanged } \\
\text { or } \\
\text { decreased }\end{array}$ & $\begin{array}{c}6 \mathrm{kcal} / \mathrm{gram} \\
\text { chow }\end{array}$ & $\begin{array}{c}5 \mathrm{kcal} / \mathrm{gram} \\
\text { chow }\end{array}$ & $\begin{array}{c}4.5 \mathrm{kcal} / \mathrm{gram} \\
\text { chow }\end{array}$ \\
\hline $\begin{array}{l}\text { Dietary } \\
\text { protein } \\
\text { content }\end{array}$ & $20 \%$ & Decreased & $\begin{array}{l}\text { Unchanged } \\
\text { or } \\
\text { decreased }\end{array}$ & $20 \%-25 \%$ & $20 \%-25 \%$ & $17 \%$ \\
\hline $\begin{array}{l}\text { Dietary } \\
\text { carbohydrate } \\
\text { content }\end{array}$ & $53 \%$ & Decreased & $\begin{array}{l}\text { Unchanged } \\
\text { or } \\
\text { decreased }\end{array}$ & $8 \%$ & $20 \%-25 \%$ & $49 \%$ \\
\hline $\begin{array}{l}\text { Dietary lipid } \\
\text { content }\end{array}$ & $5 \%$ & Decreased & Decreased & $55 \%$ & $34 \%$ & $21 \%$ \\
\hline $\begin{array}{c}\text { Induces } \\
\text { ketogenesis }\end{array}$ & No & No & Yes & Yes & No & No \\
\hline $\begin{array}{l}\text { Effect on } \\
\text { insulin sensitivity }\end{array}$ & $\mathrm{N} / \mathrm{A}$ & Increased & Increased & Increased & Decreased & Decreased \\
\hline $\begin{array}{l}\text { General trend in } \\
\text { stem cell fate }\end{array}$ & N/A & $\begin{array}{l}\text { Increased } \\
\text { self-renewal }\end{array}$ & $\begin{array}{l}\text { Increased } \\
\text { self-renewal }\end{array}$ & $\begin{array}{l}\text { Increased } \\
\text { self-renewal }\end{array}$ & $\begin{array}{c}\text { Increased } \\
\text { self-renewal, } \\
\text { carcinogenesis }\end{array}$ & $\begin{array}{c}\text { Increased } \\
\text { self-renewal, } \\
\text { carcinogenesis }\end{array}$ \\
\hline
\end{tabular}

The compositions and major effects of the macroscopic dietary interventions discussed are summarized by intervention. Note: the percent compositions are by mass and not energy composition.

acetyl-CoA in cells (Shi and Tu 2015). Ketone bodies can be generated through administration of the ketogenic diet, which is a high-fat, low-carbohydrate diet that was originally developed to treat pediatric seizure disorders (Peterman 1924; Helmholz 1927; Neal et al. 2008). This feeding paradigm again pushes an organism into a state of transient ketogenesis, wherein the cell switches from oxidizing glucose to fatty acids and ketone bodies ( $\beta$-hydroxybutyrate $[\beta-\mathrm{OHB}]$ and acetone), which derive from acetyl-CoA. Thus, the major systemic changes derived from these dietary interventions are (1) a decrease in glucose availability and oxidation, (2) an increase in lipid utilization, and (3) the production of ketone bodies as alternate carbon sources.

In contrast to dietary interventions that cause a state of ketogenesis, the high-fat diet elevates circulating glucose despite increasing insulin levels (Winzell and Ahrén 2004). By definition, the high-fat diet reduces an organism's insulin sensitivity and the efficiency by which glucose enters tissues. The high-fat diet also alters the fatty acid composition within the circulation, elevating total polyunsaturated, total n-6 ( $\omega-6)$, and cholesteryl ester fatty acids without detectable changes in triacylglycerol fatty acids (Raatz et al. 2001). Overall, the high-fat diet (1) increases glucose availability, but not necessarily utilization; (2) increases circulating levels of certain types of unsaturated fatty acids, which may act as ligands for various signaling pathways; and (3) results in insulin resistance.
Interestingly, while these different dietary paradigms exert unique effects on organismal-level metabolism, they all converge on enforcing stem cell self-renewal across several different tissue types. The molecular mechanisms that enable these disparate dietary interventions to enact similar changes in stem cell behavior are currently unknown. However, there are several factors that may contribute to these convergent phenotypes. First, the decline in glucose availability and increase in lipid utilization confers increased stemness to cells across different tissues. Second, these macroscopic dietary interventions feed into stem cell-intrinsic glucose and fatty acid metabolism. Third, dietary interventions that affect the fasted and fed states bias stem cells toward either a self-renewal or differentiation program by exacerbating changes already present when shifting between these two nutrient states. Last, the diets activate similar metabolic stress pathways and yield their common phenotypes through similar mechanisms of compensation (Fig. 1).

\section{Systemic dietary interventions converge on glucose and lipid metabolism}

Disparate dietary interventions promote stemness across tissue types

One of the most heavily studied systems with regard to organismal-level dietary interventions and their effects on stem cell behavior, normal homeostasis, and disease is 


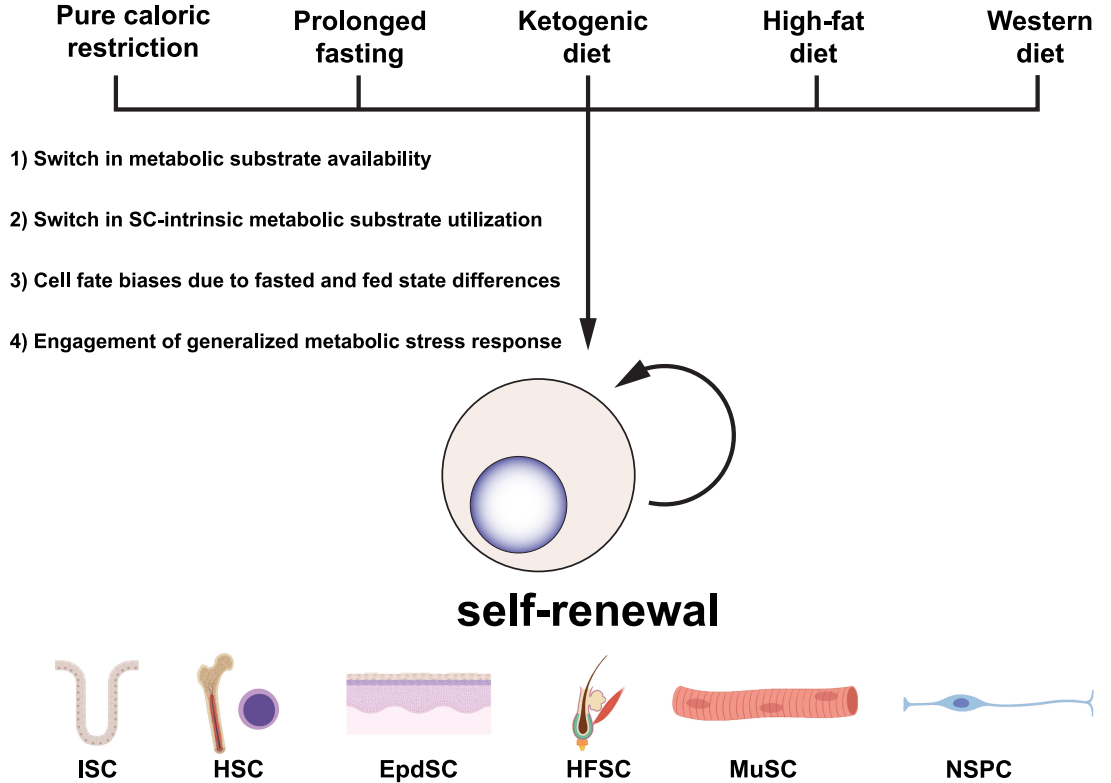

Figure 1. Disparate dietary interventions converge on stem cell self-renewal. Macroscopic dietary interventions have been shown to influence stem cell behavior across a wide array of tissue types. Here, we summarize the major findings across these tissue types and propose possible explanations for why disparate dietary interventions converge on similar phenotypes. (SC) Stem cell, (ISC) intestinal stem cell, (HSC) hematopoietic stem cell, (EpdSC) epidermal stem cells, (HFSC) hair follicle stem cell, (MuSC) muscle stem cell (satellite cell), (NSPC) neural stem/progenitor cell. the small intestine. These intestinal stem cells (ISCs) reside at the base of the crypts of Lieberkühn, where they proliferate continuously to fuel the flux of differentiating intestinal epithelial populations in the contiguous villus. Caloric restriction in this context promotes mTORC1-dependent enhanced self-renewal predominantly through Paneth cell niche-induced changes (Yilmaz et al. 2012; Igarashi and Guarente 2016), whereas high-fat or cholesterol-rich diets and intermittent fasting directly alter ISCs and progenitor function (Beyaz et al. 2016; Wang et al. 2018). The effects of a high-fat diet extend past homeostasis. In a model of ionizing radiation-induced intestinal injury, administration of a high-fat diet increased the number of surviving, proliferating, and Olfm4/OLFM4positive crypts without altering numbers of enteroendocrine or goblet cells (Beyaz et al. 2016).

Both a high-fat diet and intermittent fasting lead to ISCautonomous activation of PPAR $\delta$ signaling (Fig. 2), which enhances self-renewal through multiple mechanisms, including partial activation of a Wnt signaling program and enhancing fatty acid oxidation (Beyaz et al. 2016; Mihaylova et al. 2018). A high-fat diet and intermittent fasting could also profoundly alter the serum composition of lipids, as a high-fat diet likely enriches for circulating lipids that differ from those that are released from adipose tissue breakdown during intermittent fasting. These changes would translate to different PPAR ligands that can engage the pathway. In this regard, even though caloric restriction, a high-fat diet, and fasting all converge on enhanced crypt proliferation and survival in both homeostasis and injury-based regenerative programs, they may do so through different underlying mechanisms.

An overall metabolic state of ketogenesis can be achieved both through caloric restriction and a ketogenic diet. Whereas caloric restriction increases both ISC and Paneth cell numbers (Yilmaz et al. 2012), month-long administration of a ketogenic diet enriched the small intes- tine for both ISCs $\left(\mathrm{Lgr} 5^{\text {high }}\right)$ and Lgr $5^{\text {low }}$ short-lived proliferative intestinal progenitors, without altering differentiated Paneth cell numbers (Cheng et al. 2019). What regulates the sensitivity of different cell types to macroscopic dietary interventions remains an open question, but it may reflect the intrinsic metabolic programs of cells within the niche. For example, ISCs, but not Paneth cells, are highly enriched for the expression of the ratelimiting enzyme for ketone biosynthesis, 3-hydroxy-3methylglutaryl-CoA synthase 2 (HMGCS2), and accordingly engage in de novo ketogenesis even in the absence of a ketogenic diet. The product of ketogenesis, $\beta$-hydroxybutyrate $(\beta-\mathrm{OHB})$, can alter gene expression by inhibiting histone deacetylases (HDACs) (Shimazu et al. 2013), which enhances ISC self-renewal (Cheng et al. 2019).

Although the paucity of $\mathrm{Hmgcs} 2$ expression relative to ISCs makes it unlikely that Paneth cells biosynthesize their own $\beta-\mathrm{OHB}$, indirect effects could arise from increased availability or utilization of $\beta$-OHB in circulation (Fig. 2). Indeed, systemic $\beta$-OHB is known to increase during fasting, caloric restriction and/or ketogenic diets to millimolar concentrations, largely due to hepatic production (Cahill et al. 1966; Shimazu et al. 2013). Whether $\beta$ OHB contributes to enhanced self-renewal of ISCs under caloric restriction, a high-fat diet, and fasting remains to be explored. Additionally, while it is currently unclear whether $\beta$-OHB can accumulate at sufficient concentrations in the nucleocytosolic compartment to inhibit HDACs, $\beta$-OHB can be taken up from circulation either through passive diffusion or by facilitated transport via monocarboxylate transporters (MCTs) (Halestrap 1978; Shimazu et al. 2013). Thus, free diffusion into the nucleus through the large nuclear pores after sufficient uptake would enable high concentrations of this molecule to accumulate and alter gene expression.

While the data in ISCs provide compelling evidence that ketogenesis can promote stemness in the small intestine, 


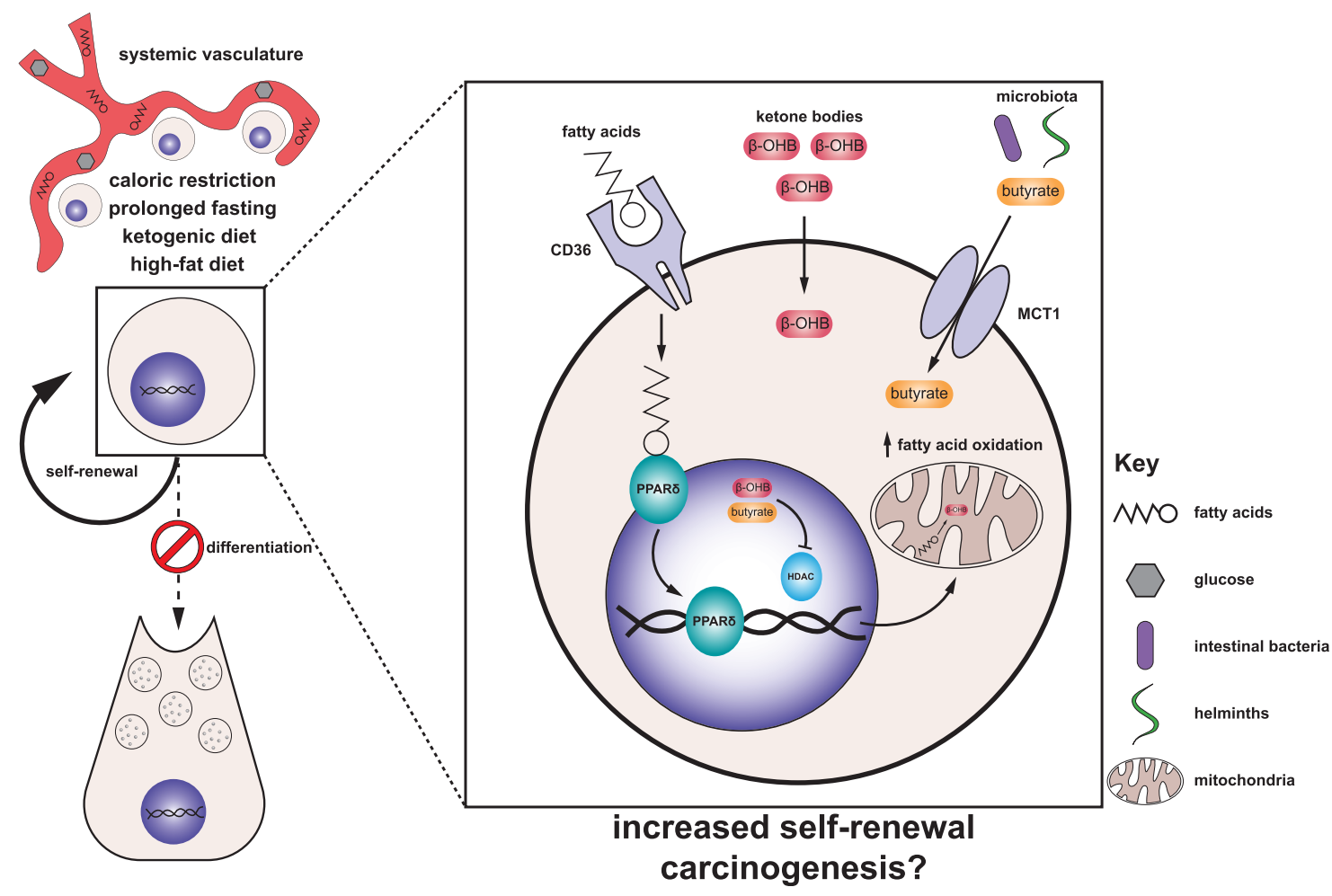

Figure 2. Integration of diet-induced metabolic changes into stem cell fate decisions. Macroscopic dietary interventions such as caloric restriction, prolonged fasting, the ketogenic diet, and a high-fat diet systemically alter an organism's metabolic state and the availability of key metabolic substrates. Interestingly, these interventions converge on pro-self-renewal phenotypes across stem cells in several different tissues. Stem cells integrate locally available metabolites such as fatty acids, ketone bodies ( $\beta$-OHB and acetone), and microbiota-derived butyrate to enact changes in stem cell fate, skewing them toward a greater propensity for stemness as well as carcinogenesis. ( $\beta$-OHB) $\beta$ Hydroxybutyrate, (CD36) cluster of differentiation 36 (fatty acid translocase), (HDAC) histone deacetylase, (MCT1) monocarboxylate transporter 1, (PPAR $\delta$ ) peroxisome proliferator-activated receptor $\delta$.

it remains to be seen whether other tissue stem cell types respond similarly to enforcing organismal ketogenesis. If so, it could be a molecular path to increasing longevity. Indeed, with regard to caloric restriction more generally, the benefits to stem cell renewal are broadly applicable across diverse tissue types. Stem cells of the muscle (satellite cells or MuSCs), bone marrow (hematopoietic stem cells, HSCs), and hair follicle (hair follicle stem cells, HFSCs) all spend much of their time in a relatively quiescent state during homeostasis, which enables them to preserve their self-renewing, tissue-regenerative capacity (Fuchs and Blau 2020). In these cases, caloric restriction favors their preservation and/or function in both young and old animals (Cerletti et al. 2012; Tang et al. 2016; Forni et al. 2017). Exactly how is less clear. For the hair follicle, which undergoes cyclical bouts of hair regeneration, the HFSC pool appeared to increase while hair coat turnover decreased when mice were restricted in their food intake (Forni et al. 2017). For muscle, the repair ability was enhanced (Cerletti et al. 2012). For the bone marrow, caloric restriction improved repopulation but impaired lymphoid differentiation capacity of the HSCs (Tang et al. 2016).

One of the complexities involved in sifting through the many beneficial effects of caloric restriction on stem cell behavior and tissue fitness is that secondary effects often surface. For instance, calorie restriction was recently shown to increase the fitness of circulating memory $\mathrm{T}$ lymphocytes, cells that allow mammals to rapidly and effectively control subsequent challenges to the immune system. Enhancing their fitness triggered the memory $\mathrm{T}$ cells to home to the bone marrow, thereby imparting enhanced protection to the HSCs and promoting their survival (Collins et al. 2019). In a similar but even more circuitous vein, short-term fasting resulted in the activation of low-energy sensor 5'-AMP-activated protein kinase (AMPK) in hepatocytes, suppressing systemic CCL2 production by PPARa and in turn reducing the number of circulating monocytes. The outcome was dampening of unwanted chronic inflammation without compromising monocyte mobilization in tissue repair, two features that favorably impact stem cells (Jordan et al. 2019). This result is consistent with the large body of literature implicating the immunosuppressive effects of starvation, suggesting that these well-documented immunosuppressive effects may benefit the host organism (Lord et al. 1998; Freitag et al. 2000). While the hormone leptin may rescue starvation-induced abrogation of $\mathrm{T}$ lymphocyte function, it is unclear whether leptin 
administration is also sufficient to rescue any defects in hematopoietic stem cell function or differentiation. Given the critical role of immune cells in regulating stem cell behavior, further dissecting how metabolic inputs influence this crosstalk will be an interesting avenue of future study.

\section{A high-fat diet can profoundly impact stem cell behavior}

In striking contrast to the metabolic effects of caloric restriction and a ketogenic diet, a high-fat diet induces obesity in mice within months. Paradoxically, even though a high-fat diet is typically associated with poor health outcome, it can in some contexts favor stem cell expansion. A case in point is embryonic development of the vertebrate hematopoietic system, where superactivating the master regulator of cholesterol biosynthesis, Srebp2, either genetically or through a high-cholesterol diet, accelerates HSC emergence (Gu et al. 2019).

Similarly, under conditions of normal intestinal homeostasis, a high-fat diet increases ISC number and proliferation. However, unlike caloric restriction and ketone and fasting diets, a high-fat diet in the intestine depletes Paneth cells via activation of PPAR $\delta$ signaling, which in turn induces Wnt target genes in ISCs (Beyaz et al. 2016). As Paneth cells are ISC progeny and ISCs in turn depend upon WNT signals from Paneth cells, this imbalance within the intestinal crypt could create a secondary response by the ISCs. Moreover, a high-fat diet endowed progenitors in the crypt with stem cell properties, which may explain the maladaptive effects of a high-fat diet such as enhanced propensity for tumorigenesis.

Further insights come from investigating the adult bone marrow niche, where a high-fat diet affects stem cell behavior, but mostly by altering stem cell fate rather than numbers per se. Thus, when hypercholesterolemiaprone mice are fed a "Western diet," their hematopoietic stem cells skew their fate away from a lymphoid lineage and towards a myeloid lineage (Christ et al. 2018). Elevated fatty food intake can also elicit an inflammatory response, which becomes all the more deleterious, given recent evidence that tissue stem cells retain an epigenetic memory of their inflammatory experiences, irrespective of whether the source of these experiences is a topical irritant, pathogen infection, or fatty diet (Naik et al. 2017; Kaufmann et al. 2018; Mitroulis et al. 2018; Naik et al. 2018; Netea et al. 2020). Consistently, abnormal myelopoiesis can exacerbate metabolic disease: In both patients and mice, enhanced inflammatory signaling in clonally expanded HSCs and their myeloid daughter cells accelerates atherosclerosis under a Western diet (Fuster et al. 2017; Jaiswal et al. 2017). Thus, the interplay between a high-fat diet and stem cell behavior may form a positive feedback loop leading to organismal health decline.

Taken together, although metabolites emanating from a high-fat diet can confer a pro-self-renewal paradigm to tissue stem cells, the long-term effects of such food remain to be evaluated, and in a number of contexts, the diet is likely to alter stem cells in ways that skew their fates and/or exacerbate their response to inflammation.

\section{Changes to intracellular glucose and lipid metabolism inform stem cell behavior}

An enticing hypothesis is that macroscopic dietary changes feed into the individual metabolism of stem cells and their niche partners to cell-intrinsically coordinate self-renewal and differentiation. These dietary changes induce critical changes with respect to glucose and fatty acid metabolism. Therefore, it is likely that these interventions shift the balance in glucose and fatty acid metabolism intracellularly.

\section{Unifying effects of lipid metabolism on self-renewal}

Availability of circulating lipids substantially increases under conditions of caloric restriction, the ketogenic diet, and Western diets, and the accompanying increased fatty acid oxidation provides insights into the possible roots of the convergence of phenotypes observed with these diets (Corton et al. 2004; Sikder et al. 2018; Steinhauser et al. 2018; Rosenbaum et al. 2019). At the level of transcriptional regulation, fasting increased PPAR-dependent fatty acid oxidation in ISCs to maintain stemness (Mihaylova et al. 2018). Orthogonal methods to enhance ISC fatty acid oxidation, such as genetic inhibition of glucose oxidation, similarly enhance ISC self-renewal (Bensard et al. 2020). Notably, ablation of PPARy in HFSCs resulted in a phenotype similar to scarring alopecia with destruction of the pilosebaceous units, indicating the importance of this pathway to proper hair follicle homeostasis (Karnik et al. 2009). Furthermore, neural stem/progenitor cells increase fatty acid oxidation during periods of quiescence and increase fatty acid synthesis after stem cell activation and during proliferative periods (Knobloch et al. 2013, 2017). Similarly, in the Drosophila germline, lipid utilization supports, whereas lipid synthesis antagonizes, stem cell maintenance (Sênos Demarco et al. 2019).

Lipids are also likely at the roots of the epigenetic memory induced in stem cells by their inflammatory experiences. In response to inflammation, both epidermal stem cells and HSCs not only activate cholesterol biosynthesis genes but also maintain them in a chromatin-poised state where they are more rapidly activated upon the next inflammatory encounter (Naik et al. 2017; Mitroulis et al. 2018). Interestingly, although cholesterol levels per se are not required, the activation of the cholesterol synthesis pathway appears to be an essential facet of the memory in HSCs, as it is erased by treatment with atorvastatin (Bekkering et al. 2018; Mitroulis et al. 2018). In HSCs, this was linked to a key role of mevalonate, an intermediate in cholesterol biosynthesis, in promoting inflammatory memory. Although these findings suggest a key role for cholesterol synthesis in epigenetically altering stem cell landscapes, the mechanisms await further investigation.

An interesting beneficial twist to increased cholesterol synthesis is the improvement of the response of certain 
stem cells to functional challenges. For HSCs, it conferred enhanced myeloablative effects of chemotherapy and abrogated the DNA damage response upon induction of systemic inflammation (Bekkering et al. 2018; Mitroulis et al. 2018). For epidermal stem cells, although not necessarily rooted in cholesterol synthesis per se, inflammatory memory enhanced their ability to heal wounds (Naik et al. 2017). The ability of different cell types to gain fitness through lipid metabolism provides insights into why seemingly deleterious metabolic outcomes related to increased cholesterol levels may have been evolutionarily conserved.

\section{Glucose utilization dictates stem cell behavior}

Cells oxidize glucose to fuel energy production and anabolic pathways to support growth and proliferation. Under fasting conditions in vivo, glucose feeds into the tricarboxylic acid (TCA) cycle by circulating lactate in all tissues except the brain, and glucose primarily tends to feed into glycolysis and the pentose phosphate pathway versus other metabolic pathways (Hui et al. 2017). In the fed state, direct glucose oxidation increases, but lactate oxidation remains the primary mechanism by which glucose feeds the TCA cycle. It remains unknown whether these shifts in glucose metabolism at the tissue level also occur in stem cells during fasting and refeeding. Studying this through new technologies such as imaging mass spectrometry may provide new insights into dietary regulation of stem cell behavior.

Emerging evidence suggests that glucose utilization can regulate a stem cell's decision to remain quiescent or activate. For example, HSCs are thought to reside in hypoxic areas of the niche and elevate glycolysis during periods of quiescence (Parmar et al. 2007; Simsek et al. 2010; Takubo et al. 2010; Nombela-Arrieta et al. 2013). Notably, maintenance of HSC quiescence requires the action of pyruvate dehydrogenase kinase, which, by preventing the shunting of pyruvate for mitochondrial oxidation, enhances glycolysis (Takubo et al. 2013). Similarly, inhibition of the glycolytic enzyme hexokinase (HK2) and lactate dehydrogenase (LDH) during normoxia resulted in proliferation defects in neural progenitor cells (Zheng et al. 2016). Conversely, HFSCs and ISCs rely on glycolysis to sustain proliferation. HFSCs that cannot activate LDH activity, which sustains redox balance to promote glycolysis, fail to activate hair cycling (Flores et al. 2017). Similarly, ISCs that cannot oxidize glucose in the TCA cycle have enhanced proliferation and self-renewal. Finally, recent evidence also suggests that glucose fate regulates stem cell differentiation: Blocking glucose entry into the TCA cycle in epidermal stem cells promotes their differentiation (Goguet-Rubio et al. 2016; Baksh et al. 2020), whereas it enhances ISC self-renewal (Schell et al. 2017; Bensard et al. 2020). Altogether, these data suggest cell type-specific effects of glucose metabolism on stem cell proliferation and fate. Notably, blocking glucose oxidation in the TCA cycle triggers compensatory oxidation of other substrates, including FAs, which may provide a link between decreased glucose availability and enhanced fatty acid oxidation in stem cells upon dietary interventions (Corton et al.
2004; Sikder et al. 2018; Steinhauser et al. 2018; Rosenbaum et al. 2019).

\section{Pathogens and microbiota can alter the metabolic milieu of tissue stem cell niches}

Diet can confer profound changes to the composition of gastrointestinal microbiota, which can subsequently alter the local metabolic milieu to which stem cells are exposed (Schulz et al. 2014; Olson et al. 2018). One of the most fascinating examples of the effects of microbes and pathogens to impact the metabolic milieu of stem cell environments comes from helminths, common intestinal parasites that, if allowed to persist, can elicit an inflammatory response. Recently, it was shown that helminth-derived metabolites, specifically succinate, can stimulate resident innate immune cells, called ILC2s, that respond by producing IL-13. In turn, IL-13 skews the ISCs to produce an excess of Tuft cells, which in turn secrete IL-25, which then further fuels ILC2 proliferation to create a vicious inflammatory circuit (Schneider et al. 2018). Thus, metabolites derived from gastrointestinal helminths can skew cell fate of ISCs and bias differentiation toward a specific lineage.

While the identification of certain metabolites that dictate stem cell behavior is ongoing, the source of these metabolites continues to elude the field. However, in certain circumstances, the gastrointestinal microbiota is emerging as a key source of these metabolites. Lactobacillus-derived lactate promoted intestinal epithelial turnover in the colon, suggesting this microbiota-derived source of carbon can augment stem cell self-renewal (Okada et al. 2013). In an esophageal tumor initiation model, the high-fat diet-associated increase in $\mathrm{Lgr}^{+}$progenitors was dependent on the microbiota within the gastrointestinal tract, as germ-free mice did not display the same propensity for tumor formation, and fecal microbiota transfer from mice fed a high-fat diet to mice fed the control diet also displayed increased tumor formation (Münch et al. 2019). Although a molecular mechanism is still needed that would link metabolites produced by distinct species of microbiota, general dysbiosis caused by a high-fat diet has been associated with tumor progression through lack of secreted butyrate as a waste product by the microbiota (Schulz et al. 2014). Of note, butyrate can also serve as an HDAC inhibitor (Candido et al. 1978). Thus, both a high-fat diet and ketogenesis can enhance stemness through enforcing self-renewal via microbiota-derived butyrate and $\beta$-OHB accumulation, respectively (Fig. 2). Since butyrate is a more potent HDAC inhibitor than $\beta$-OHB (Shimazu et al. 2013), a high-fat diet may be enforcing gene expression to enable carcinogenesis and may explain why increased carcinogenesis is not observed under ketogenic conditions.

Pathogens additionally elicit profound changes in organismal metabolism that may influence stem cell behavior. For example, induction of anorexia or feeding behaviors in response to pathogens influences host survival (Wang et al. 2016; Rao et al. 2017). Glucose availability and utilization by the host in response to pathogens 
has been linked to pathogen virulence and host survival (Wang et al. 2016; Sanchez et al. 2018). Given the known effects of diet on stem cell behavior and the critical role stem cells play in response to pathogens and tissue injury, it will be of interest to interrogate more deeply how microbes, organismal metabolism, and stem cell behavior intersect during infectious processes.

\section{Fasting and refed states}

While many studies have demonstrated effects of fasting on stem cell behavior, these studies do not focus on how physiologic refeeding after fasting influences stem cell behavior and the tissue and lineage-dependent differences in stem cell fate due to overall metabolic status of an organism (fasting or fed). Furthermore, nonautonomous factors that integrate into the control of stem cells during fasting and refeeding have largely been unexplored. Studies in the Drosophila midgut have demonstrated refeeding after nutrient deprivation initiates signals for ISCs to proliferate. These responses were nonautonomous and dependent on insulin signaling (Choi et al. 2011; O'Brien et al. 2011). Furthermore, intrinsic insulin signaling regulates the stability of adherens junctions between ISCs and their daughter cells, as insulin receptor knockdown ISCs increase the stability of these junctions to prohibit ISC proliferation (Choi et al. 2011). Cycles of prolonged fasting increased survival in mice subjected to chemotherapy-induced bone marrow ablation and increased chimerism in noncompetitive transplant models (Cheng et al. 2014). Strikingly, fasting specifically depleted circulating white blood cells and increased HSC numbers, but these numbers were rescued by refeeding. In the Peyer's patches of the small intestine, fasting-refeeding markedly depleted tissue B-cells and caused some to migrate to the bone marrow and return to the Peyer's patches upon refeeding (Nagai et al. 2019). In the central nervous system, refeeding stimulates hypothalamic neurons that subsequently activate a subset of NSCs to proliferate, driving production of specific neuronal subtypes (Paul et al. 2017). These results imply that the transition between fasting and refeeding can dynamically change the tissue microenvironment, highlighting the importance of elucidating the underlying mechanisms during this metabolic transition. They also implicate heretofore unidentified growth factor or hormonal signals as potential mediators of these phenotypes and the dynamic balance of stem cell state during periods of fasting and refeeding, independent of diet-induced changes in nutrient availability. Thus, both nutrient availability and hormonal changes may exert discrete effects on stem cell function.

\section{Effects of generalized metabolic stress}

Macroscopic dietary interventions that prompt similar changes in stem cell behavior may engage the same metabolic signaling pathways to enable cells to mount a response to subsequent nutrient stresses. Caloric restriction/prolonged fasting, ketogenesis, and a high-fat diet all diminish the levels of circulating glucose. Numerous intracellular signaling pathways sense systemic glucose availability. mTORC1 senses glucose through the glycolytic intermediate dihydroxyacetone phosphate in a Rag-GTPase-dependent mechanism (Efeyan et al. 2013; Orozco et al. 2020). Although its effects on stem cell behavior remain to be explored, carbohydrate response element binding protein (ChREBP) functions as a glucose sensor in the liver by binding to promoters of glucose-sensitive genes upon activation by glycolytic intermediates together with its obligate binding partner Max-like protein X (MLX) (Yamashita et al. 2001; Stoeckman et al. 2004; Ma et al. 2005, 2006). AMPK may play a role if these systemic dietary interventions result in a lack of biosynthetic materials for growth, as AMPK turns on in these circumstances (González et al. 2020). Additionally, many of these diets increase PPAR signaling due to their intimate ties with lipid metabolism. Insulin sensitivity can also change in response to dietary interventions (Kinzig et al. 2010; Rosenbaum et al. 2019). However, the effect of dietary changes on stem cell-intrinsic insulin signaling remains mostly unexplored. The sole exception is in ISCs where insulin receptor ablation prevents ISC proliferation by stabilizing adherens junctions /Choi et al. 2011). Overall, this area represents a relatively unexplored avenue in the field that will help to better understand the similarities and differences between these dietary interactions.

\section{How diet can impact cancer}

Stem cells are increasingly recognized as the root of malignancy, as oncogenic mutations lock stem cells in states of ongoing self-renewal that facilitate tumorigenesis (Bjerkvig et al. 2005; Kreso and Dick 2014; Ge and Fuchs 2018). Consistent with the effects of organismal metabolism on stem cell behavior, diet can confer profound effects on the course of tumor initiation and progression in vivo. In ad libitum-fed mice, intestinal stem cells but not progenitors represent the cell of origin of intestinal adenomas and adenocarcinomas (Barker et al. 2009). Strikingly, a high-fat diet was sufficient to bestow tumor-forming capacity in premalignant intestinal progenitors independent of the niche. Enforced PPAR $\delta$ signaling through pharmacologic administration of a PPAR $\delta$ agonist was able to phenocopy this finding, suggesting that a high-fat diet works at least in part through PPAR $\delta$ signaling (Beyaz et al. 2016).

Intriguingly, a high-fat diet, and not an oncogenic mutation, served as the so-called second hit that enables tumor initiation in this one-hit model in ISCs. These data demonstrate that exogenous metabolic shifts in homeostasis imparted tumor-initiating capacity to a cell type that is not normally recognized as tumor-initiating. The fact that intermittent fasting has not yielded the same propensity for tumor formation suggests that a high-fat diet and fasting differ with regard to the quantity or strength of the PPAR ligands generated by the dietary intervention. In the same vein, administration of a Western diet or perturbation of cholesterol homeostasis altered stem cell fate 
during homeostasis and during tumor initiation. A Western diet increased the number of polyps formed in premalignant mouse models of colorectal carcinoma (Baltgalvis et al. 2009). The increased tumorigenic features of a Western diet on premalignant ISCs suggests that a Western diet also promotes stem cell self-renewal. That said, in the hematopoietic system, a Western diet skewed hematopoietic stem cell fate from lymphoid to myeloid lineages (Christ et al. 2018), a feature that may also play out in the intestinal stem cell niche, where multiple ISC fates including those altering inflammation are also possible.

Concordant with the data in ISCs, a high-fat diet administered to mice during an esophageal carcinoma tumor initiation model increased Lgr5 $^{+}$progenitor cells and promoted tumor growth. These mice had premalignant esophageal lesions, and a high-fat diet again acted as the second hit to initiate tumors in situ (Münch et al. 2019). Overall, it is becoming clear that the metabolic state of an organism serves as a key constituent of the tissue milieu that can govern stem cell fate during homeostasis and disease.

In a model of oral squamous cell carcinoma, a high-fat diet promoted metastasis in a CD36-dependent fashion (Pascual et al. 2017). Since the tumor-initiating cells in squamous cell carcinoma normally up-regulate the fatty acid transporter CD36, the findings suggest that uptake of fatty acids into tumor-initiating cells, and likely their oxidation, is at least partially responsible for the observed increase in metastasis after a high-fat diet. Similarly, CD36-mediated fatty acid uptake enhances leukemic stem cell resistance to chemotherapy, promoting disease progression (Ye et al. 2016). Overall, these phenotypes begin to explain the pro-stemness effects of the dietary manipulations discussed above (Fig. 2). Might therapeutically increasing fatty acid oxidation provide a tempting new avenue to safeguard stem cell populations across tissue types? Perhaps, but since prolonged bias toward selfrenewal potentially confers increased cancer risk, more work must be done to tease apart which permissive factors enable increased self-renewal without promoting carcinogenesis.

\section{Future directions}

\section{Metabolic pathways for future investigation}

Although much is known about how these dietary interventions alter glucose and lipid metabolism, how the dietary interventions affect other central carbon pathways is relatively unexplored (Box 1). With regard to central carbon metabolism, more work must be done to understand exactly how these dietary interventions affect central carbon pathways such as glycolysis, the pentose phosphate pathway, TCA cycle, and amino acid biosynthesis, especially through organismal isotopic tracing studies as has been previously described during conditions of standard mouse chow (Hui et al. 2017). For example, does decreasing glucose availability lower the rate of glycolysis and limit intermediaries used for amino acid synthesis? Do these changes in amino acid synthesis exert downstream effects on cell fate by altering the availability of molecules that govern the epigenome of a cell (Box 1)?

Amino acid availability and metabolism are known regulators of stemness (Shyh-Chang et al. 2013; Carey et al. 2015; Taya et al. 2016; Wang et al. 2019; Baksh et al. 2020). Similar to dietary interventions, such as a high-fat diet, that abrogate insulin sensitivity, increased circulating levels of branched-chain amino acids (BCAAs) have long been associated with insulin resistance and type 2 diabetes (Newgard 2012). Notably, BCAA metabolism can modulate stem cell function through the enzyme branched chain amino transaminase 1 (BCAT1), which converts BCAAs to branched-chain ketoacids through transamination of $\alpha$-ketoglutarate (aKG) to glutamate.

aKG is a key TCA cycle intermediate in the mitochondrial matrix. However, aKG also acts as a cosubstrate for a class of enzymes called aKG-dependent dioxygenases, many of which serve as histone and DNA demethylases and can enact changes in nuclear gene expression. Furthermore, $\alpha \mathrm{KG}^{\prime} \mathrm{s}$ immediate downstream metabolite in the TCA cycle, succinate, can competitively inhibit aKG-dependent dioxygenases and antagonize the effects of aKG (Schvartzman et al. 2018).

Leukemia cells up-regulate BCAT1 and deplete $\alpha \mathrm{KG}$, which results in inhibition of ten-eleven translocation (Tet) DNA demethylases and subsequent DNA hypermethylation (Hattori et al. 2017; Raffel et al. 2017). While maintenance of increased total aKG:succinate pools maintains pluripotency in mouse embryonic stem cells, aKG accumulation has been implicated as a prodifferentiation factor across several tissue types, such as premalignant epidermal and intestinal stem cells and pancreatic cancer cells (Morris et al. 2019; Baksh and Finley 2020; Baksh et al. 2020; Tran et al. 2020). Notably, other transaminases such as phosphoserine aminotransferase (PSAT1), alanine aminotransferase (GPT1/2), and aspartate aminotransferase (GOT1/2) can also contribute to cytosolic accumulation or depletion of $\alpha \mathrm{KG}$. For example, activation or suppression of the serine biosynthesis pathway can alter $\alpha \mathrm{KG}$ levels through modulation of the activity of PSAT1 (Possemato et al. 2011; Baksh et al. 2020). The fact that aKG can alter gene expression and stem cell fate also suggests that accumulation or reduction of this metabolite must eventually occur in the nucleocytosolic compartment, possibly through the action of these

\section{Box 1. Future directions and outstanding questions}

- How do dietary interventions affect pathways involved in central carbon metabolism?

- Can dietary interventions regulate the epigenome through modulation of intracellular metabolite levels?

- How do dietary interventions reshape the stem cell niche?

- How might nonautonomously produced growth factors signal to stem cells and prime them to adapt to tissue stress? 
transaminases or through the mitochondrial $\alpha \mathrm{KG} / \mathrm{malate}$ carrier protein (SLC25A11) (Palmieri et al. 1972). Therefore, exploring the role of BCAAs and understanding whether any other amino acids that feed into these pathways are altered in the macroscopic dietary interventions described herein may be an interesting avenue of further research in understanding how systemic metabolic perturbations regulate stem cell fate in vivo.

\section{Dietary interventions can fundamentally change the cellular composition of the niche}

There is evidence that these macroscopic dietary interventions can substantially change the cellular census of stem cell niche (Box 1). For example, caloric restriction can reshape the local HFSC niche by decreasing white adipose depots in the dermis (Forni et al. 2017). Interestingly, local white adipocytes can maintain HFSC quiescence by providing inhibitory BMP2 (Plikus et al. 2008). Paradoxically however, contraction of the local white adipose tissue due to caloric restriction would disinhibit HFSCs and enable activation of the hair cycle, contrary to the observations of decreased hair turnover. Further work will be needed to reconcile these differences as well as elucidate the compositional changes across tissue types induced by macroscopic dietary perturbations. Taking cues from the ISC niche, further investigation is warranted to determine how sensitive or responsive the stem cells in these tissues are to caloric restriction versus any identified or unidentified niche players in their local microenvironments that regulate stem cell fate similar to Paneth cells.

\section{Conclusion}

Stem cells integrate cues from their local niche to inform their behavior and cell fate. While metabolites continue to emerge as key members of the niche, there has been little focus on how the macroscopic dietary status of an organism might contribute to stem cell behavior. Comparisons between caloric restriction/prolonged fasting, the ketogenic diet, and high-fat diets suggest the importance of the balance between glucose and fatty acid utilization as oxidative substrates and beg the question why these disparate dietary interactions converge on similar results. Thus, a closer investigation of how these major dietary interventions augment the balance of intracellular metabolites and their respective biosynthetic and catabolic pathways is warranted. Studies from fasting and refeeding implicate nonautonomous production of insulin as a mediator. Additionally, this finding implies that other types of growth factors can signal to stem cells how their behavior might change to adapt to local tissue stress, independent of differences in diet-induced nutrient availability (Box 1). Overall, more work must be done to better link how macroscopic dietary changes impact the overall metabolic status of an organism, how this status contributes to the stem cell niche, and finally how these changes translate into changes in stem cell fate and behavior. A better understanding of these processes will lead to a bet- ter understanding of homeostatic and disease states as well as suggest new avenues of inquiry for therapeutic intervention in a wide array of diseases, especially those characterized by states of inflammation and cancer.

\section{Acknowledgments}

We are grateful to the many friends and colleagues in the stem cell and metabolism fields whose work inspired us to write this review. We centered this review largely on three common dietary restrictions, drawing parallels and distinctions between them and the responses they elicit from tissue stem cells. While text constraints limited our focus, we tried to illustrate paradigms gained from examining the impact of pathogens, microbiota, and stress, including oncogenic stress, on metabolism in the tissue microenvironment and its resident stem cells. Similarly, due to reference constraints, we regret that we could not cite all of the worthy papers on this topic. From our treatise, we hope that the exciting questions in stem cell biology and future avenues for exploring how tissue stem cells cope with metabolic changes will shine through and inspire new work. E.F. is an Investigator of the Howard Hughes Medical Institute and the Rebecca C. Lancefield Professor. J.S.S.N. and S.C.B. are predoctoral fellows of the Weill Cornell/Rockefeller/Sloan Kettering Tri-Institutional Medical Scientist Training Program (T32-GM007739). S.C.B. is a Ruth Kirschstein National Institues of Health (NIH) predoctoral fellow (F31-CA236465). This work was supported by grants from the NIH (R01-AR050452, R01-AR31737, R01-AR27883, E.F.), the Starr Foundation (E.F., J.S.S.N., and S.C.B.), and NYSTEM C32585GG (E.F.).

\section{References}

Baksh SC, Finley LWS. 2020. Metabolic coordination of cell fate by a-ketoglutarate-dependent dioxygenases. Trends Cell Biol 31: 24-36. doi:10.1016/j.tcb.2020.09.010

Baksh SC, Todorova PK, Gur-Cohen S, Hurwitz B, Ge Y, Novak JSS, Tierney MT, dela Cruz-Racelis J, Fuchs E, Finley LWS. 2020. Extracellular serine controls epidermal stem cell fate and tumour initiation. Nat Cell Biol 22: 779-790. doi:10 .1038/s41556-020-0525-9

Baltgalvis KA, Berger FG, Peña MMO, Davis JM, Carson JA. 2009. The interaction of a high-fat diet and regular moderate intensity exercise on intestinal polyp development in ApcMin/+ mice. Cancer Prev Res 2: 641-649. . doi:10.1158/1940-6207 .CAPR-09-0017

Barker N, Ridgway RA, Van Es JH, Van De Wetering M, Begthel H, Van Den Born M, Danenberg E, Clarke AR, Sansom OJ, Clevers H. 2009. Crypt stem cells as the cells-of-origin of intestinal cancer. Nature 457: 608-611. doi:10.1038/ nature07602

Bekkering S, Arts RJW, Novakovic B, Kourtzelis I, van der Heijden CDCC, Li Y, Popa CD, ter Horst R, van Tuijl J, NeteaMaier RT, et al. 2018. Metabolic induction of trained immunity through the mevalonate pathway. Cell 172: 135-146.e9. doi:10.1016/j.cell.2017.11.025

Bensard CL, Wisidagama DR, Olson KA, Berg JA, Krah NM, Schell JC, Nowinski SM, Fogarty S, Bott AJ, Wei P, et al. 2020. Regulation of tumor initiation by the mitochondrial pyruvate carrier. Cell Metab 31: 284-300.e7. doi:10.1016/j.cmet .2019 .11 .002

Beyaz S, Mana MD, Roper J, Kedrin D, Saadatpour A, Hong S-J, Bauer-Rowe KE, Xifaras ME, Akkad A, Arias E, et al. 2016. 
High-fat diet enhances stemness and tumorigenicity of intestinal progenitors. Nature 531: 53-58. . doi:10.1038/ nature 17173

Bjerkvig R, Tysnes BB, Aboody KS, Najbauer J, Terzis AJA. 2005. The origin of the cancer stem cell: current controversies and new insights. Nat Rev Cancer 5: 899-904. doi:10.1038/ $\operatorname{nrc} 1740$

Cahill GF, Herrera MG, Morgan AP, Soeldner JS, Steinke J, Levy PL, Reichard GA, Kipnis DM. 1966. Hormone-fuel interrelationships during fasting. J Clin Invest 45: 1751-1769. doi:10 $.1172 / \mathrm{JCI} 105481$

Candido EPM, Reeves R, Davie JR. 1978. Sodium butyrate inhibits histone deacetylation in cultured cells. Cell 14: 105-113. doi:10.1016/0092-8674(78)90305-7

Carey BW, Finley LWS, Cross JR, Allis CD, Thompson CB. 2015. Intracellular $a$-ketoglutarate maintains the pluripotency of embryonic stem cells. Nature 518: 413-416. doi:10.1038/ nature13981

Cerletti M, Jang YC, Finley LWS, Haigis MC, Wagers AJ. 2012. Short-term calorie restriction enhances skeletal muscle stem cell function. Cell Stem Cell 10: 515-519. doi:10.1016/ j.stem.2012.04.002

Cheng CW, Adams GB, Perin L, Wei M, Zhou X, Lam BS, Da Sacco S, Mirisola M, Quinn DI, Dorff TB, et al. 2014. Prolonged fasting reduces IGF-1/PKA to promote hematopoietic-stemcell-based regeneration and reverse immunosuppression. Cell Stem Cell 14: 810-823. doi:10.1016/j.stem.2014.04.014

Cheng CW, Biton M, Haber AL, Gunduz N, Eng G, Gaynor LT, Tripathi S, Calibasi-Kocal G, Rickelt S, Butty VL, et al. 2019. Ketone body signaling mediates intestinal stem cell homeostasis and adaptation to diet. Cell 178: 1115-1131.e15. doi:10.1016/j.cell.2019.07.048

Choi NH, Lucchetta E, Ohlstein B. 2011. Nonautonomous regulation of Drosophila midgut stem cell proliferation by the insulin-signaling pathway. Proc Natl Acad Sci 108: 1870218707. doi:10.1073/pnas.1109348108

Christ A, Günther P, Lauterbach MAR, Duewell P, Biswas D, Pelka K, Scholz CJ, Oosting M, Haendler K, Baßler K, et al. 2018. Western diet triggers NLRP3-dependent innate immune reprogramming. Cell 172: 162-175.e14. doi:10.1016/j.cell .2017 .12 .013

Collins N, Han SJ, Enamorado M, Link VM, Huang B, Moseman EA, Kishton RJ, Shannon JP, Dixit D, Schwab SR, et al. 2019. The bone marrow protects and optimizes immunological memory during dietary restriction. Cell 178: 1088-1101.e15. doi:10.1016/j.cell.2019.07.049

Corton JC, Apte U, Anderson SP, Limaye P, Yoon L, Latendresse J, Dunn C, Everitt JI, Voss KA, Swanson C, et al. 2004. Mimetics of caloric restriction include agonists of lipid-activated nuclear receptors. J Biol Chem 279: 46204-46212. doi:10.1074/jbc .M406739200

Efeyan A, Zoncu R, Chang S, Gumper I, Snitkin H, Wolfson RL, Kirak O, Sabatini DD, Sabatini DM. 2013. Regulation of mTORC1 by the Rag GTPases is necessary for neonatal autophagy and survival. Nature 493: 679-683. doi:10.1038/ nature 11745

Flores A, Schell J, Krall AS, Jelinek D, Miranda M, Grigorian M, Braas D, White AC, Zhou JL, Graham NA, et al. 2017. Lactate dehydrogenase activity drives hair follicle stem cell activation. Nat Cell Biol 19: 1017-1026. doi:10.1038/ncb3575

Forni MF, Peloggia J, Braga TT, Chinchilla JEO, Shinohara J, Navas CA, Camara NOS, Kowaltowski AJ. 2017. Caloric restriction promotes structural and metabolic changes in the skin. Cell Rep 20: 2678-2692. doi:10.1016/j.celrep.2017.08 .052
Freitag KA, Saker KE, Thomas E, Kalnitsky J. 2000. Acute starvation and subsequent refeeding affect lymphocyte subsets and proliferation in cats. J Nutr 130: 2444-2449. doi:10.1093/jn/ 130.10.2444

Fuchs E, Blau HM. 2020. Tissue stem cells: architects of their niches. Cell Stem Cell 27: 532-556. doi:10.1016/j.stem.2020 .09 .011

Fuster JJ, MacLauchlan S, Zuriaga MA, Polackal MN, Ostriker AC, Chakraborty R, Wu CL, Sano S, Muralidharan S, Rius C, et al. 2017. Clonal hematopoiesis associated with TET2 deficiency accelerates atherosclerosis development in mice. Science 355: 842-847. doi:10.1126/science.aag1381

Ge Y, Fuchs E. 2018. Stretching the limits: from homeostasis to stem cell plasticity in wound healing and cancer. Nat Rev Genet 19: 311-325. doi:10.1038/nrg.2018.9

Goguet-Rubio P, Seyran B, Gayte L, Bernex F, Sutter A, Delpech H, Linares LK, Riscal R, Repond C, Rodier G, et al. 2016. E4F1-mediated control of pyruvate dehydrogenase activity is essential for skin homeostasis. Proc Natl Acad Sci 113: 11004-11009. doi:10.1073/pnas.1602751113

Gonzales KAU, Fuchs E. 2017. Skin and its regenerative powers: an alliance between stem cells and their niche. Dev Cell 43: 387-401. doi:10.1016/j.devcel.2017.10.001

González A, Hall MN, Lin SC, Hardie DG. 2020. AMPK and TOR: the yin and yang of cellular nutrient sensing and growth control. Cell Metab 31: 472-492. doi:10.1016/j.cmet.2020.01.015

Gu Q, Yang X, Lv J, Zhang J, Xia B, Kim JD, Wang R, Xiong F, Meng S, Clements TP, et al. 2019. AIBP-mediated cholesterol efflux instructs hematopoietic stem and progenitor cell fate. Science 363: 1085-1088. doi:10.1126/science.aav1749

Halestrap AP. 1978. Pyruvate and ketone-body transport across the mitochondrial membrane. Exchange properties, $\mathrm{pH}$-dependence and mechanism of the carrier. Biochem I 172: 377-387. doi:10.1042/bj1720377

Hattori A, Tsunoda M, Konuma T, Kobayashi M, Nagy T, Glushka J, Tayyari F, McSkimming D, Kannan N, Tojo A, et al. 2017. Cancer progression by reprogrammed BCAA metabolism in myeloid leukaemia. Nature 545: 500-504. doi:10 $.1038 /$ nature22314

Helmholz HF. 1927. The treatment of epilepsy in childhood: five years' experience with the ketogenic diet. J Am Med Assoc 88: 2028-2032. doi:10.1001/jama.1927.02680520018008

Hui S, Ghergurovich JM, Morscher RJ, Jang C, Teng X, Lu W, Esparza LA, Reya T, Zhan L, Yanxiang Guo J, et al. 2017. Glucose feeds the TCA cycle via circulating lactate. Nature 551: 115-118. doi:10.1038/nature24057

Igarashi M, Guarente L. 2016. mTORC1 and SIRT1 cooperate to foster expansion of gut adult stem cells during calorie restriction. Cell 166: 436-450. doi:10.1016/j.cell.2016.05.044

Intlekofer AM, Finley LWS. 2019. Metabolic signatures of cancer cells and stem cells. Nat Metab 1: 177-188. doi:10.1038/ s42255-019-0032-0

Jaiswal S, Natarajan P, Silver AJ, Gibson CJ, Bick AG, Shvartz E, McConkey M, Gupta N, Gabriel S, Ardissino D, et al. 2017. Clonal hematopoiesis and risk of atherosclerotic cardiovascular disease. $N$ Engl I Med 377: 111-121. doi:10.1056/ NEJMoa 1701719

Jewell JL, Russell RC, Guan KL. 2013. Amino acid signalling upstream of mTOR. Nat Rev Mol Cell Biol 14: 133-139. doi:10 $.1038 / \mathrm{nrm} 3522$

Jordan S, Tung N, Casanova-Acebes M, Chang C, Cantoni C, Zhang D, Wirtz TH, Naik S, Rose SA, Brocker CN, et al. 2019. Dietary intake regulates the circulating inflammatory monocyte pool. Cell 178: 1102-1114.e17. doi:10.1016/j.cell .2019.07.050 
Karnik P, Tekeste Z, McCormick TS, Gilliam AC, Price VH, Cooper KD, Mirmirani P. 2009. Hair follicle stem cell-specific PPAR $\gamma$ deletion causes scarring alopecia. I Invest Dermatol 129: $1243-1257$. doi:10.1038/jid.2008.369

Kaufmann E, Sanz J, Dunn JL, Khan N, Mendonça LE, Pacis A, Tzelepis F, Pernet E, Dumaine A, Grenier JC, et al. 2018. BCG educates hematopoietic stem cells to generate protective innate immunity against tuberculosis. Cell 172: 176-190.e19. doi:10.1016/j.cell.2017.12.031

Kinzig KP, Honors MA, Hargrave SL. 2010. Insulin sensitivity and glucose tolerance are altered by maintenance on a ketogenic diet. Endocrinology 151: 3105-3114. doi:10.1210/en.20100175

Knobloch M, Braun SMG, Zurkirchen L, Von Schoultz C, Zamboni N, Araúzo-Bravo MJ, Kovacs WJ, Karalay Ö, Suter U, Machado RAC, et al. 2013. Metabolic control of adult neural stem cell activity by Fasn-dependent lipogenesis. Nature 493: 226-230. doi:10.1038/nature 11689

Knobloch M, Pilz GA, Ghesquière B, Kovacs WJ, Wegleiter T, Moore DL, Hruzova M, Zamboni N, Carmeliet P, Jessberger S. 2017. A fatty acid oxidation-dependent metabolic shift regulates adult neural stem cell activity. Cell Rep 20: 2144-2155. doi:10.1016/j.celrep.2017.08.029

Kreso A, Dick JE. 2014. Evolution of the cancer stem cell model. Cell Stem Cell 14: 275-291. doi:10.1016/j.stem.2014.02.006

Lord GM, Matarese G, Howard JK, Baker RJ, Bloom SR, Lechler RI. 1998. Leptin modulates the T-cell immune response and reverses starvation-induced immunosuppression. Nature 394: 897-901. doi:10.1038/29795

Ma L, Tsatsos NG, Towle HC. 2005. Direct role of ChREBP.Mlx in regulating hepatic glucose-responsive genes. I Biol Chem 280: 12019-12027. doi:10.1074/jbc.M413063200

Ma L, Robinson LN, Towle HC. 2006. ChREBP.Mlx is the principal mediator of glucose-induced gene expression in the liver. I Biol Chem 281: 28721-28730. doi:10.1074/jbc .M601576200

Martínez-Reyes I, Chandel NS. 2020. Mitochondrial TCA cycle metabolites control physiology and disease. Nat Commun 11: 1-11. doi:10.1038/s41467-019-13668-3

Mihaylova MM, Sabatini DM, Yilmaz ÖH. 2014. Dietary and metabolic control of stem cell function in physiology and cancer. Cell Stem Cell 14: 292-305. doi:10.1016/j.stem.2014.02 .008

Mihaylova MM, Cheng CW, Cao AQ, Tripathi S, Mana MD, Bauer-Rowe KE, Abu-Remaileh M, Clavain L, Erdemir A, Lewis CA, et al. 2018. Fasting activates fatty acid oxidation to enhance intestinal stem cell function during homeostasis and aging. Cell Stem Cell 22: 769-778.e4. doi:10.1016/j.stem .2018.04.001

Mitroulis I, Ruppova K, Wang B, Chen LS, Grzybek M, Grinenko T, Eugster A, Troullinaki M, Palladini A, Kourtzelis I, et al. 2018. Modulation of myelopoiesis progenitors is an integral component of trained immunity. Cell 172: 147-161.e12. doi:10.1016/j.cell.2017.11.034

Morris JP, Yashinskie J, Koche R, Chandwani R, Tian S, Chen CC, Baslan T, Marinkovic ZS, Sánchez-Rivera FJ, Leach SD, et al. 2019. a-Ketoglutarate links p53 to cell fate during tumour suppression. Nature 573: 595-599. doi:10.1038/ s41586-019-1577-5

Münch NS, Fang HY, Ingermann J, Maurer HC, Anand A, Kellner V, Sahm V, Wiethaler M, Baumeister T, Wein F, et al. 2019. High-fat diet accelerates carcinogenesis in a mouse model of Barrett's esophagus via interleukin 8 and alterations to the gut microbiome. Gastroenterology 157: 492-506.e2. doi:10 $.1053 /$ j.gastro.2019.04.013
Nagai M, Noguchi R, Takahashi D, Morikawa T, Koshida K, Komiyama S, Ishihara N, Yamada T, Kawamura YI, Muroi $\mathrm{K}$, et al. 2019. Fasting-refeeding impacts immune cell dynamics and mucosal immune responses. Cell 178: 1072-1087.e14. doi:10.1016/j.cell.2019.07.047

Naik S, Larsen SB, Gomez NC, Alaverdyan K, Sendoel A, Yuan S, Polak L, Kulukian A, Chai S, Fuchs E. 2017. Inflammatory memory sensitizes skin epithelial stem cells to tissue damage. Nature 550: 475-480. doi:10.1038/nature24271

Naik S, Larsen SB, Cowley CJ, Fuchs E. 2018. Two to tango: dialog between immunity and stem cells in health and disease. Cell 175: 908-920. doi:10.1016/j.cell.2018.08.071

Neal EG, Chaffe H, Schwartz RH, Lawson MS, Edwards N, Fitzsimmons G, Whitney A, Cross JH. 2008. The ketogenic diet for the treatment of childhood epilepsy: a randomised controlled trial. Lancet Neurol 7: 500-506. doi:10.1016/S14744422(08)70092-9

Netea MG, Domínguez-Andrés J, Barreiro LB, Chavakis T, Divangahi M, Fuchs E, Joosten LAB, van der Meer JWM, Mhlanga MM, Mulder WJM, et al. 2020. Defining trained immunity and its role in health and disease. Nat Rev Immunol 20: 375-388. doi:10.1038/s41577-020-0285-6

Newgard CB. 2012. Interplay between lipids and branched-chain amino acids in development of insulin resistance. Cell Metab 15: 606-614. doi:10.1016/j.cmet.2012.01.024

Nombela-Arrieta C, Pivarnik G, Winkel B, Canty KJ, Harley B, Mahoney JE, Park SY, Lu J, Protopopov A, Silberstein LE. 2013. Quantitative imaging of haematopoietic stem and progenitor cell localization and hypoxic status in the bone marrow microenvironment. Nat Cell Biol 15: 533-543. doi:10 $.1038 / \mathrm{ncb} 2730$

O'Brien LE, Soliman SS, Li X, Bilder D. 2011. Altered modes of stem cell division drive adaptive intestinal growth. Cell 147: 603-614. doi:10.1016/j.cell.2011.08.048

Okada T, Fukuda S, Hase K, Nishiumi S, Izumi Y, Yoshida M, Hagiwara T, Kawashima R, Yamazaki M, Oshio T, et al. 2013. Microbiota-derived lactate accelerates colon epithelial cell turnover in starvation-refed mice. Nat Commun 4: 110. doi: $10.1038 /$ ncomms 2668

Olson CA, Vuong HE, Yano JM, Liang QY, Nusbaum DI, Hsiao EY. 2018. The gut microbiota mediates the anti-seizure effects of the ketogenic diet. Cell 173: 1728-1741.e13. doi:10.1016/j .cell.2018.04.027

Orozco JM, Krawczyk PA, Scaria SM, Cangelosi AL, Chan SH, Kunchok T, Lewis CA, Sabatini DM. 2020. Dihydroxyacetone phosphate signals glucose availability to mTORC1. Nat Metab 2: 893-901. doi:10.1038/s42255-020-0250-5

Palmieri F, Quagliariello E, Klingenberg M. 1972. Kinetics and specificity of the oxoglutarate carrier in rat-liver mitochondria. Eur I Biochem 29: 408-416. doi:10.1111/j.1432-1033 .1972.tb02003.x

Parmar K, Mauch P, Vergilio JA, Sackstein R, Down JD. 2007. Distribution of hematopoietic stem cells in the bone marrow according to regional hypoxia. Proc Natl Acad Sci 104: 54315436. doi:10.1073/pnas.0701152104

Pascual G, Avgustinova A, Mejetta S, Martín M, Castellanos A, Attolini CSO, Berenguer A, Prats N, Toll A, Hueto JA, et al. 2017. Targeting metastasis-initiating cells through the fatty acid receptor CD36. Nature 541: 41-45. doi:10.1038/ nature 20791

Paul A, Chaker Z, Doetsch F. 2017. Hypothalamic regulation of regionally distinct adult neural stem cells and neurogenesis. Science 356: 1383-1386. doi:10.1126/science.aal3839 
Peterman MG. 1924. The ketogenic diet in the treatment of epilepsy. Am I Dis Child 28: 28. doi:10.1001/archpedi.1924 .04120190031004

Plikus MV, Mayer JA, De La Cruz D, Baker RE, Maini PK, Maxson R, Chuong CM. 2008. Cyclic dermal BMP signalling regulates stem cell activation during hair regeneration. Nature 451: 340-344. doi:10.1038/nature06457

Possemato R, Marks KM, Shaul YD, Pacold ME, Kim D, Birsoy K, Sethumadhavan S, Woo H-K, Jang HG, Jha AK, et al. 2011. Functional genomics reveal that the serine synthesis pathway is essential in breast cancer. Nature 476: 346-350. doi:10 $.1038 /$ nature 10350

Pugh TD, Klopp RG, Weindruch R. 1999. Controlling caloric consumption: protocols for rodents and rhesus monkeys. Neurobiol Aging 20: 157-165. doi:10.1016/S0197-4580(99) 00043-3

Raatz SK, Bibus D, Thomas W, Kris-Etherton P. 2001. Human nutrition and metabolism: total fat intake modifies plasma fatty acid composition in humans. I Nutr 131: 231-234. doi:10 $.1093 /$ in/131.2.231

Raffel S, Falcone M, Kneisel N, Hansson J, Wang W, Lutz C, Bullinger L, Poschet G, Nonnenmacher Y, Barnert A, et al. 2017. BCAT1 restricts akG levels in AML stem cells leading to IDHmut-like DNA hypermethylation. Nature 551: 384-388. doi:10.1038/nature24294

Rao S, Schieber AMP, O'Connor CP, Leblanc M, Michel D, Ayres JS. 2017. Pathogen-mediated inhibition of anorexia promotes host survival and transmission. Cell 168: 503-516.e12. doi:10.1016/j.cell.2017.01.006

Rosenbaum M, Hall KD, Guo J, Ravussin E, Mayer LS, Reitman ML, Smith SR, Walsh BT, Leibel RL. 2019. Glucose and lipid homeostasis and inflammation in humans following an isocaloric ketogenic diet. Obesity 27: 971-981. doi:10.1002/oby .22468

Sanchez KK, Chen GY, Schieber AMP, Redford SE, Shokhirev MN, Leblanc M, Lee YM, Ayres JS. 2018. Cooperative metabolic adaptations in the host can favor asymptomatic infection and select for attenuated virulence in an enteric pathogen. Cell 175: 146-158.e15. doi:10.1016/j.cell.2018.07 .016

Schell JC, Wisidagama DR, Bensard C, Zhao H, Wei P, Tanner J, Flores A, Mohlman J, Sorensen LK, Earl CS, et al. 2017. Control of intestinal stem cell function and proliferation by mitochondrial pyruvate metabolism. Nat Cell Biol 19: 1027-1036. doi:10.1038/ncb3593

Schneider C, O'Leary CE, von Moltke J, Liang HE, Ang QY, Turnbaugh PJ, Radhakrishnan S, Pellizzon M, Ma A, Locksley RM. 2018. A metabolite-triggered tuft cell-ILC2 circuit drives small intestinal remodeling. Cell 174: 271-284.e14. doi:10 $.1016 /$ j.cell.2018.05.014

Schulz MD, Atay Ç, Heringer J, Romrig FK, Schwitalla S, Aydin B, Ziegler PK, Varga J, Reindl W, Pommerenke C, et al. 2014. High-fat-diet-mediated dysbiosis promotes intestinal carcinogenesis independently of obesity. Nature 514: 508-512. doi:10 $.1038 /$ nature 13398

Schvartzman JM, Thompson CB, Finley LWS. 2018. Metabolic regulation of chromatin modifications and gene expression. $J$ Cell Biol 217: 2247-2259. doi:10.1083/jcb.201803061

Sênos Demarco R, Uyemura BS, D'Alterio C, Jones DL. 2019. Mitochondrial fusion regulates lipid homeostasis and stem cell maintenance in the Drosophila testis. Nat Cell Biol 21: 710720. doi:10.1038/s41556-019-0332-3

Shi L, Tu BP. 2015. Acetyl-CoA and the regulation of metabolism: mechanisms and consequences. Curr Opin Cell Biol 33: 125131. doi:10.1016/j.ceb.2015.02.003
Shimazu T, Hirschey MD, Newman J, He W, Shirakawa K, Le Moan N, Grueter CA, Lim H, Saunders LR, Stevens RD, et al. 2013. Suppression of oxidative stress by $\beta$-hydroxybutyrate, an endogenous histone deacetylase inhibitor. Science 339: 211-214. doi:10.1126/science.1227166

Shyh-Chang N, Locasale JW, Lyssiotis CA, Zheng Y, Teo RY, Ratanasirintrawoot $\mathrm{S}$, Zhang J, Onder $\mathrm{T}$, Unternaehrer JJ, Zhu H, et al. 2013. Influence of threonine metabolism on Sadenosylmethionine and histone methylation. Science 339: 222-226. doi:10.1126/science.1226603

Sikder K, Shukla SK, Patel N, Singh H, Rafiq K. 2018. High fat diet upregulates fatty acid oxidation and ketogenesis via intervention of PPAR- $\gamma$. Cell Physiol Biochem 48: 1317-1331. doi:10 $.1159 / 000492091$

Simsek T, Kocabas F, Zheng J, DeBerardinis RJ, Mahmoud AI, Olson EN, Schneider JW, Zhang CC, Sadek HA. 2010. The distinct metabolic profile of hematopoietic stem cells reflects their location in a hypoxic niche. Cell Stem Cell 7: 380-390. doi:10.1016/j.stem.2010.07.011

Steinhauser ML, Olenchock BA, O'Keefe J, Lun M, Pierce KA, Lee H, Pantano L, Klibanski A, Shulman GI, Clish CB, et al. 2018. The circulating metabolome of human starvation. JCI insight 3: e121434. doi:10.1172/jci.insight.121434

Stoeckman AK, Ma L, Towle HC. 2004. Mlx is the functional heteromeric partner of the carbohydrate response element-binding protein in glucose regulation of lipogenic enzyme genes. J Biol Chem 279: 15662-15669. doi:10.1074/jbc.M311301200

Takubo K, Goda N, Yamada W, Iriuchishima H, Ikeda E, Kubota Y, Shima H, Johnson RS, Hirao A, Suematsu M, et al. 2010. Regulation of the HIF-1 $\alpha$ level is essential for hematopoietic stem cells. Cell Stem Cell 7: 391-402. doi:10.1016/j.stem .2010.06.020

Takubo K, Nagamatsu G, Kobayashi CI, Nakamura-Ishizu A, Kobayashi H, Ikeda E, Goda N, Rahimi Y, Johnson RS, Soga T, et al. 2013. Regulation of glycolysis by Pdk functions as a metabolic checkpoint for cell cycle quiescence in hematopoietic stem cells. Cell Stem Cell 12: 49-61. doi:10.1016/j.stem .2012.10.011

Tang D, Tao S, Chen Z, Koliesnik IO, Calmes PG, Hoerr V, Han B, Gebert N, Zörnig M, Löffler B, et al. 2016. Dietary restriction improves repopulation but impairs lymphoid differentiation capacity of hematopoietic stem cells in early aging. $J$ Exp Med 213: 535-553. doi:10.1084/jem.20151100

Taya Y, Ota Y, Wilkinson AC, Kanazawa A, Watarai H, Kasai M, Nakauchi H, Yamazaki S. 2016. Depleting dietary valine permits nonmyeloablative mouse hematopoietic stem cell transplantation. Science 354: 1152-1155. doi:10.1126/science .aag3145

Tran TQ, Hanse EA, Habowski AN, Li H, Ishak Gabra MB, Yang Y, Lowman XH, Ooi AM, Liao SY, Edwards RA, et al. 2020. $\alpha-$ Ketoglutarate attenuates Wnt signaling and drives differentiation in colorectal cancer. Nat Cancer 1:345-358. doi:10.1038/ s43018-020-0035-5

Wang A, Huen SC, Luan HH, Yu S, Zhang C, Gallezot JD, Booth CI, Medzhitov R. 2016. Opposing effects of fasting metabolism on tissue tolerance in bacterial and viral inflammation. Cell 166: 1512-1525.e12. doi:10.1016/j.cell.2016.07 .026

Wang B, Rong X, Palladino END, Wang J, Fogelman AM, Martín MG, Alrefai WA, Ford DA, Tontonoz P. 2018. Phospholipid remodeling and cholesterol availability regulate intestinal stemness and tumorigenesis. Cell Stem Cell 22: 206-220.e4. doi:10.1016/j.stem.2017.12.017

Wang Z, Yip LY, Lee JHJ, Wu Z, Chew HY, Chong PKW, Teo CC, Ang HYK, Peh KLE, Yuan J, et al. 2019. Methionine is a 
metabolic dependency of tumor-initiating cells. Nat Med 25: 825-837. doi: 10.1038/s41591-019-0423-5

Ward PS, Thompson CB. 2012. Signaling in control of cell growth and metabolism. Cold Spring Harb Perspect Biol 4: 1-15. doi:10.1101/cshperspect.a006783

Winzell MS, Ahrén B. 2004. The high-fat diet-fed mouse: a model for studying mechanisms and treatment of impaired glucose tolerance and type 2 diabetes. Diabetes 53: S215-S219. doi:10.2337/diabetes.53.suppl_3.S215

Yamashita H, Takenoshita M, Sakurai M, Bruick RK, Henzel WJ, Shillinglaw W, Arnot D, Uyeda K. 2001. A glucose-responsive transcription factor that regulates carbohydrate metabolism in the liver. Proc Natl Acad Sci 98: 9116-9121. doi:10.1073/ pnas. 161284298
Ye H, Woolthuis CM, Stranahan AW, Park CY, Minhajuddin M, Gasparetto M, Stevens B, Pei S, Jordan CT. 2016. Leukemic stem cells evade chemotherapy by metabolic adaptation to an adipose tissue niche. Cell Stem Cell 19: 23-37. doi:10 $.1016 /$ j.stem.2016.06.001

Yilmaz ÖH, Katajisto P, Lamming DW, Gültekin Y, Bauer-Rowe KE, Sengupta S, Birsoy K, Dursun A, Yilmaz VO, Selig M, et al. 2012. mTORC1 in the Paneth cell niche couples intestinal stem-cell function to calorie intake. Nature 486: 490-495. doi:10.1038/nature11163

Zheng X, Boyer L, Jin M, Mertens J, Kim Y, Ma L, Ma L, Hamm M, Gage FH, Hunter T. 2016. Metabolic reprogramming during neuronal differentiation from aerobic glycolysis to neuronal oxidative phosphorylation. Elife 5: e13374. doi:10.7554/eLife.13374 


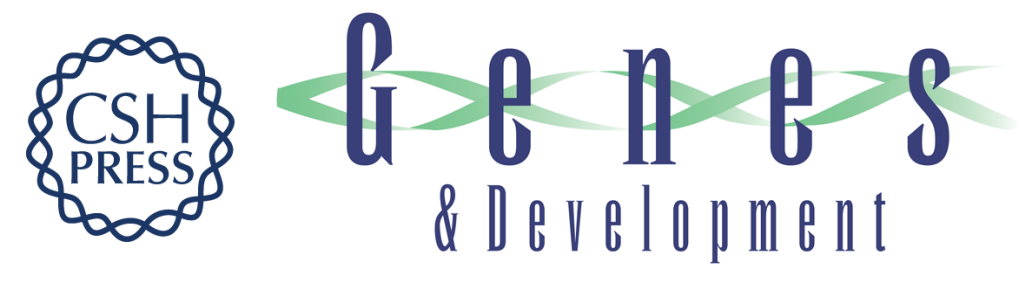

\title{
Dietary interventions as regulators of stem cell behavior in homeostasis and disease
}

\author{
Jesse S.S. Novak, Sanjeethan C. Baksh and Elaine Fuchs
}

Genes Dev. 2021, 35:

Access the most recent version at doi:10.1101/gad.346973.120

\begin{tabular}{|c|c|}
\hline References & $\begin{array}{l}\text { This article cites } 103 \text { articles, } 22 \text { of which can be accessed free at: } \\
\text { http://genesdev.cshlp.org/content/35/3-4/199.full.html\#ref-list-1 }\end{array}$ \\
\hline $\begin{array}{r}\text { Creative } \\
\text { Commons } \\
\text { License }\end{array}$ & $\begin{array}{l}\text { This article is distributed exclusively by Cold Spring Harbor Laboratory Press for the first } \\
\text { six months after the full-issue publication date (see } \\
\text { http://genesdev.cshlp.org/site/misc/terms.xhtml). After six months, it is available under a } \\
\text { Creative Commons License (Attribution-NonCommercial } 4.0 \text { International), as described } \\
\text { at http://creativecommons.org/licenses/by-nc/4.0/. }\end{array}$ \\
\hline $\begin{array}{l}\text { Email Alerting } \\
\text { Service }\end{array}$ & $\begin{array}{l}\text { Receive free email alerts when new articles cite this article - sign up in the box at the top } \\
\text { right corner of the article or click here. }\end{array}$ \\
\hline
\end{tabular}

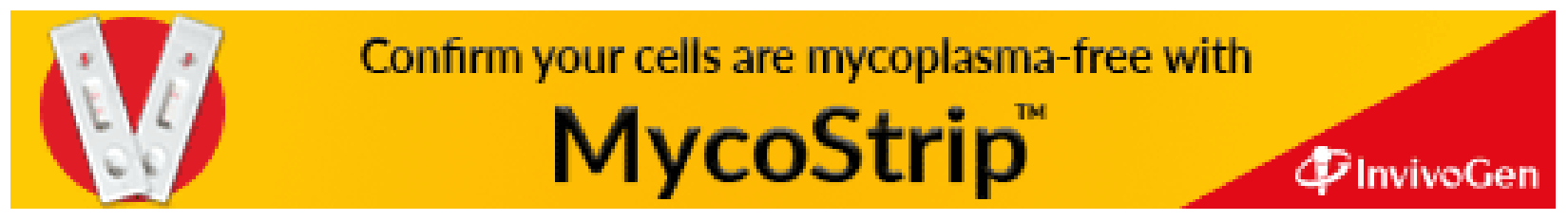

